Supplemental information to manuscript:

\title{
Suppression of new particle formation from monoterpene oxidation by $\mathrm{NO}_{\mathrm{x}}$
}

J. Wildt, Th. F. Mentel, A. Kiendler-Scharr, Th. Hoffmann, S. Andres, M. Ehn, E. Kleist, P. Müsgen, F. Rohrer, Y. Rudich, M. Springer, R. Tillmann, A. Wahner

This supplement is divided into 7 sections. In section S1 an overview on our treatment of the photochemical system is given. Section S2 describes the way to determine $\mathrm{P}\left(\mathrm{O}_{3}\right)$. Section S3 gives more details on power law dependencies mentioned in the manuscript. Section S4 describes determination of $\left[\mathrm{RO}_{2}\right]$ from deviation of $\frac{\left[\mathrm{NO}_{2}\right]}{[\mathrm{NO}]}$ from PSS and section S5 gives details on our estimations of relative peroxy radical concentrations at low $\left[\mathrm{NO}_{\mathrm{x}}\right]_{0}$ conditions. Section S6 aims to confirm that the formation of first generation permutation reaction products is not the rate limiting step for new particle formation. Section S7 gives information on our determinations of $\mathrm{J}_{7}$ and its uncertainties.

S1. Basic reactions and considerations regarding the power law dependence observed between ozone production rates and new particle formation

In the absence of volatile organic compounds (VOC) and hydroxyl radicals (OH), nitrogen monoxide (NO), nitrogen dioxide $\left(\mathrm{NO}_{2}\right)$, and ozone $\left(\mathrm{O}_{3}\right)$ reach equilibrium concentrations within minutes in a photochemical system. The equilibrium conditions are termed as photostationary steady state (PSS, Leighton, 1961):

$\frac{\left[N O_{2}\right]}{[N O]}=\frac{k_{1} \cdot\left[O_{3}\right]}{J\left(\mathrm{NO}_{2}\right)}$

$\left(\mathrm{k}_{1}=1.8 \times 10^{-14} \mathrm{~cm}^{3} \mathrm{~s}^{-1}=\right.$ rate constant for the reaction of NO with $\mathrm{O}_{3}$, IUPAC, 2009, $\mathrm{J}\left(\mathrm{NO}_{2}\right)$ $=\mathrm{NO}_{2}$ photolysis rate). 
1 The ratio $\frac{\left[\mathrm{NO}_{2}\right]}{[\mathrm{NO}]}$ deviates from that in Equation ES1 when the chemical system contains VOC

2 and $\mathrm{OH}$. This deviation from PSS is due to reactions of NO with peroxy radicals $\left(\mathrm{RO}_{2}\right)$.

3 Reactions of $\mathrm{NO}$ with $\mathrm{RO}_{2}$ either form $\mathrm{NO}_{2}$ in reaction $\mathrm{R} 2 \mathrm{a}$ or organic nitrates in reaction

4 R2b:

5

$6 \mathrm{NO}+\mathrm{RO}_{2} \rightarrow \mathrm{RO}+\mathrm{NO}_{2}$

$7 \mathrm{NO}+\mathrm{RO}_{2} \rightarrow \mathrm{RONO}_{2}$

8

9

Reaction R2a is the basic reaction for photochemical ozone formation. The rate of net ozone 10 formation $\left(\mathrm{P}\left(\mathrm{O}_{3}\right)\right)$ is written as:

$P\left(O_{3}\right)=\sum_{i}\left(\left[R O_{2}^{i}\right] \cdot k^{i} \cdot Y^{i}\left(O_{3}\right)\right) \cdot[N O]$

13

In Equation ES2, $R O_{2}^{i}$ is the specific peroxy radical, $\mathrm{k}^{\mathrm{i}}$ the rate coefficient of $R O_{2}^{i}$ with $\mathrm{NO}$, and $Y^{i}\left(\mathrm{O}_{3}\right)$ is the branching ratio of ozone formation in reaction $\mathrm{R} 2$ (reaction $\mathrm{R} 2=$ reaction $\mathrm{R} 2 \mathrm{a}+$ reaction $\mathrm{R} 2 \mathrm{~b}$ ) with the specific peroxy radical $R O_{2}^{i}$. The production rate of organic nitrate formation $\left(\mathrm{P}\left(\mathrm{RONO}_{2}\right)\right)$ is given by:

$P\left(\mathrm{RONO}_{2}\right)=\sum_{i}\left(\left[\mathrm{RO}_{2}^{i}\right] \cdot k^{i} \cdot Y^{i}\left(\mathrm{RONO}_{2}\right)\right) \cdot[\mathrm{NO}]$

In Equation ES3 $\mathrm{Y}^{i}\left(\mathrm{RONO}_{2}\right)$ is the branching ratio of organic nitrate formation in reaction R2.

For simplification we write Equations ES2 and ES3 in the form:

27

and

29

$P\left(\mathrm{RONO}_{2}\right)=k_{2} \cdot[\mathrm{NO}] \cdot\left[\mathrm{RO}_{2}\right] \cdot \mathrm{Y}\left(\mathrm{RONO}_{2}\right)$ 
$1 k_{2}\left(=k_{2 a}+k_{2 b}\right)$ is an average rate constant for reaction R2 $\left(9 \times 10^{-12} \mathrm{~cm}^{3} \mathrm{~s}^{-1}\right.$, IUPAC, 2009)

2 and $Y\left(\mathrm{O}_{3}\right)$ and $Y\left(\mathrm{RONO}_{2}\right)$ are average branching ratios. Assuming that reactions R2a and

$3 \mathrm{R} 2 \mathrm{~b}$ are the only pathways of $\mathrm{RO}_{2}+\mathrm{NO}$ reactions, $Y\left(\mathrm{RONO}_{2}\right)=1-Y\left(\mathrm{O}_{3}\right)$.

4

5

8

9

10

28 The derivative of $\frac{k_{3} \cdot\left[\mathrm{RO}_{2}\right]}{k_{2} \cdot[\mathrm{NO}]}$ versus $\mathrm{NO}$ is:

29

$30 \frac{\partial\left(\frac{k_{3} \cdot\left[R O_{2}\right]}{k_{2} \cdot[\mathrm{NO}]}\right)}{\partial[\mathrm{NO}]}=-\frac{\frac{k_{3}}{k_{2}} \cdot\left[\mathrm{RO}_{2}\right]}{[\mathrm{NO}]^{2}}$

$$
P(P R P)=k_{3} \cdot\left[R O_{2}\right] \cdot\left[R O_{2}\right]
$$
ES5:

$$
\frac{k_{3} \cdot\left[R O_{2}\right]}{k_{2} \cdot[N O]}
$$

This ratio is equal to the ratio $\frac{P(P R P)}{P\left(O_{3}\right)+P\left(R_{N N O}\right)}$ :

$$
\frac{k_{3} \cdot\left[R O_{2}\right]}{k_{2} \cdot[N O]}=\frac{P(P R P)}{P\left(O_{3}\right)+P\left(R O N O_{2}\right)}
$$

Reaction R3a forms hydroperoxides. Reaction R3b forms various products including alkoxy radicals, diols, ketones (e.g. master chemical mechanism, MCM), and probably also alkylperoxides (e.g. Hallquist et al., 2009). We termed the sum of all products of reaction R3 as permutation reaction products, RPR. Production rates of PRP, P(PRP) can be written as:

where $k_{3}$ is an average rate constant for a given $\mathrm{RO}_{2}$ mix. Note that the term $\mathrm{RO}_{2}$ is used to include $\mathrm{HO}_{2}$. The ratio of the rates at which reaction $\mathrm{R} 3$ and $\mathrm{R} 2$ proceed is given by equation 
2 Hence the derivative of $\frac{P(P R P)}{P\left(O_{3}\right)+P\left(R_{\left.N N O_{2}\right)}\right.}$ versus [NO] is also given by the right term in 3 Equation ES7.

4

5 Considering that for a given photochemical system $\mathrm{P}\left(\mathrm{O}_{3}\right)$ and $\mathrm{P}\left(\mathrm{RONO}_{2}\right)$ are related by $6 \frac{Y\left(\mathrm{O}_{3}\right)}{\mathrm{Y}\left(\mathrm{RONO}_{2}\right)}$, the sum $\mathrm{P}\left(\mathrm{O}_{3}\right)+\mathrm{P}\left(\mathrm{RONO}_{2}\right)$ can be expressed as:

7

$8 \quad P\left(\mathrm{O}_{3}\right)+P\left(\mathrm{RONO}_{2}\right)=P\left(\mathrm{O}_{3}\right)+\frac{Y\left(\mathrm{RONO}_{2}\right)}{Y\left(\mathrm{O}_{3}\right)} \cdot P\left(\mathrm{O}_{3}\right)$

9

$13 \frac{P(P R P)}{P\left(O_{3}\right)+P\left(R_{O N O}\right)}=\frac{P(P R P)}{\left(1+\frac{Y\left(R O N O_{2}\right)}{Y\left(O_{3}\right)}\right) \cdot P\left(O_{3}\right)}$

$17-\frac{\partial\left(\frac{P(P R P)}{P\left(O_{3}\right)}\right)}{\partial[N O]}=\left(1+\frac{Y\left(R O N O_{2}\right)}{Y\left(O_{3}\right)}\right) \cdot \frac{\frac{k_{3}}{k_{2}} \cdot\left[R O_{2}\right]}{[N O]^{2}}$

$27-\frac{\partial\left(\frac{P(P R P)}{P\left(O_{3}\right)}\right)}{\partial[N O]}=$ const $\cdot \frac{\left[R O_{2}\right]}{[N O]^{2}}$

At constant contribution of $\mathrm{HO}_{2}$ and other $\mathrm{RO}_{2}$ radicals $\frac{Y\left(\mathrm{RONO}_{2}\right)}{Y\left(\mathrm{O}_{3}\right)}$ should be constant. If so, $\mathrm{P}\left(\mathrm{O}_{3}\right)$ may serve as a proxy for $\mathrm{RO}_{2}$ consumption in reaction $\mathrm{R} 2$ :

It thus follows that $\mathrm{P}(\mathrm{PRP})$ and $\mathrm{P}\left(\mathrm{O}_{3}\right)$ in dependence of [NO] is coupled according to:

Branching ratios as well as the rate constants $\mathrm{k}_{3}$ and $\mathrm{k}_{2}$ are determined by the peroxy radical pattern. The $\mathrm{RO}_{2}$ pattern itself is controlled by the BVOC mixture, by [OH] and by [NO] . In particular contributions of $\mathrm{HO}_{2}$ are important because $\mathrm{Y}\left(\mathrm{RONO}_{2}\right)$ is essentially zero for $\mathrm{HO}_{2}$. For simplicity we assume that branching ratios and rate constants were constant from experiment to experiment because the same BVOC mixtures were added in all experiments. This assumption allowed to express the NO induced changes of the ratio $\mathrm{P}(\mathrm{PRP}) / \mathrm{P}\left(\mathrm{O}_{3}\right)$ by exchanging $\frac{k_{3}}{k_{2}} \cdot\left(1+\frac{Y\left(R O N O_{2}\right)}{Y\left(O_{3}\right)}\right)$ by a constant (const): 
1 with const being a proportionality factor. The results of our experiments a posteriori verified

2 the validity of the above given assumption.

3

4 In a photochemical system $\frac{P(P R P)}{P\left(O_{3}\right)}$ may change with varying $[N O]$ in a very complicated 5 manner because variations of $[\mathrm{NO}]$ should result in variations of $\left[\mathrm{RO}_{2}\right]$. Here we distinguish 6 two cases:

7 (1) The peroxy radical production rate, $\mathrm{P}\left(\mathrm{RO}_{2}\right)$, stays constant independent of NO. In this case increasing $[\mathrm{NO}]$ should cause a decrease of $\left[\mathrm{RO}_{2}\right]$ and the power law dependence should show an exponent below -2 .

(2) $\left[\mathrm{RO}_{2}\right]$ is independent of $[\mathrm{NO}]$ and nearly constant. It follows that $\frac{\partial\left(\frac{P(P R P)}{P\left(O_{3}\right)}\right)}{\partial[N O]}=$ const . $11 \frac{1}{[N O]^{2}}$ meaning that the ratio $\frac{P(P R P)}{P\left(O_{3}\right)}$ will change with varying [NO] in a way describable by power law dependence with an exponent of -2 . One mechanism by which $\left[\mathrm{RO}_{2}\right]$ can stay constant and thus independent of [NO] is an increasing production rate of $\mathrm{RO}_{2} \mathrm{P}\left(\mathrm{RO}_{2}\right)$ due to increasing steady state $[\mathrm{OH}]$.

\section{S2: Determination of $\mathbf{P}\left(\mathrm{O}_{3}\right)$}

Rates of photochemical ozone production, $\mathrm{P}\left(\mathrm{O}_{3}\right)$, were determined considering the following source and loss terms for $\mathrm{O}_{3}$.

\section{Source terms for $\mathrm{O}_{3}$ :}

a) Net addition to the chamber: $V \cdot \frac{\partial\left[O_{3}\right]}{\partial t}=F \cdot\left(\left[O_{3}\right]_{i n}-\left[O_{3}\right]\right)$

with $\mathrm{V}=$ volume of the chamber, $F=$ air flow through the chamber, $\left[\mathrm{O}_{3}\right]_{\text {in }}=$ concentration of $\mathrm{O}_{3}$ in the ingoing and $\left[\mathrm{O}_{3}\right]=$ concentration of $\mathrm{O}_{3}$ in the outgoing air stream. The reaction chamber was operated as continuously stirred tank reactor with air mixing rates much higher than exchange rates of air. Thus the ozone concentration measured at chamber outlet, $\left[\mathrm{O}_{3}\right]$, is the average ozone concentration in the chamber. Note that in case of photochemical ozone formation $\left[\mathrm{O}_{3}\right]$ will be higher than $\left[\mathrm{O}_{3}\right]_{\mathrm{in}}$. Process a) may switch from a source term to a loss term. 
b) $\mathrm{NO}_{2}$ photolysis: $V \cdot \frac{\partial\left[\mathrm{O}_{3}\right]}{\partial t}=V \cdot J\left(\mathrm{NO}_{2}\right) \cdot\left[\mathrm{NO}_{2}\right]$

with $\mathrm{J}\left(\mathrm{NO}_{2}\right)$ = rate of $\mathrm{NO}_{2}$ photolysis and assuming that $\mathrm{J}\left(\mathrm{NO}_{2}\right)$ limits the rate of process b) because the subsequent reaction: $\mathrm{O}^{3} \mathrm{P}+\mathrm{O}_{2}+\mathrm{M} \rightarrow \mathrm{O}_{3}+\mathrm{M}$ is much faster than $\mathrm{NO}_{2}$ photolysis.

\section{Loss terms for $\mathrm{O}_{3}$ :}

c) Reactions with NO: $V \cdot \frac{\partial\left[O_{3}\right]}{\partial t}=-V \cdot k_{1} \cdot[\mathrm{NO}] \cdot\left[\mathrm{O}_{3}\right]$

d) Ozone photolysis: $V \cdot \frac{\partial\left[O_{3}\right]}{\partial t}=-V \cdot J\left(O^{1} D\right) \cdot\left[O_{3}\right] \cdot f\left(\left[H_{2} O\right]\right)$

with $f\left(\left[\mathrm{H}_{2} \mathrm{O}\right]\right)=$ branching ratio of $\mathrm{O}^{1} \mathrm{D}+\mathrm{H}_{2} \mathrm{O}$ reactions over $\mathrm{O}^{1} \mathrm{D}$ quenching to $\mathrm{O}^{3} \mathrm{P}$ by $\mathrm{O}_{2}$ and $\mathrm{N}_{2}$ which leads to reformation of $\mathrm{O}_{3}$.

e) Ozone reactions with BVOC: $V \cdot \frac{\partial\left[O_{3}\right]}{\partial t}=-V \cdot k_{B V O C} \cdot\left[O_{3}\right] \cdot[B V O C]$ with $k_{B V O C}=$ average rate constant for $\mathrm{BVOC}+\mathrm{O}_{3}$ reactions.

f) Ozone reactions with $\mathrm{OH}: V \cdot \frac{\partial\left[\mathrm{O}_{3}\right]}{\partial t}=-V \cdot k_{O H} \cdot\left[\mathrm{O}_{3}\right] \cdot[\mathrm{OH}]$ with $k_{O H}=$ rate constant of $\mathrm{OH}+\mathrm{O}_{3}$ reactions.

g) Ozone reactions with $\mathrm{HO}_{2}: \mathrm{V} \cdot \frac{\partial\left[\mathrm{O}_{3}\right]}{\partial t}=-\mathrm{V} \cdot k_{\mathrm{HO} 2} \cdot\left[\mathrm{O}_{3}\right] \cdot\left[\mathrm{HO}_{2}\right]$ with $k_{\mathrm{HO} 2}=$ rate constant of $\mathrm{HO}_{2}+\mathrm{O}_{3}$ reactions.

h) Wall losses: $V \cdot \frac{\partial\left[O_{3}\right]}{\partial t}=v^{w} \cdot A^{w} \cdot\left[O_{3}\right]$ with $v^{w}=$ deposition velocity of ozone to the walls of the chamber with the wall area $A^{w}$. 
1 Dominant source term is $\mathrm{NO}_{2}$ photolysis, dominant loss term is reaction of $\mathrm{O}_{3}$ with NO. If the system is in PSS, both rates are equal and cancel out. In the presence of VOC and OH, ozone production by $\mathrm{NO}_{2}$ photolysis exceeds ozone losses in reactions with NO. The difference between (b) and (c) is attributed to reaction R2a and termed as ozone production rate:

$P\left(\mathrm{O}_{3}\right)=k_{2} \cdot[\mathrm{NO}] \cdot\left[\mathrm{RO}_{2}\right] \cdot Y\left(\mathrm{O}_{3}\right)$

Under atmospheric conditions ozone losses due to ozone photolysis and reactions of $\mathrm{O}_{3}$ with $\mathrm{OH}, \mathrm{HO}_{2}$, and BVOC are quite low and can be neglected for estimation of $\mathrm{P}\left(\mathrm{O}_{3}\right)$. In our reaction chamber the situation was different because $\mathrm{J}\left(\mathrm{O}^{1} \mathrm{D}\right),[\mathrm{OH}],[\mathrm{BVOC}]$ and most probably also $\left[\mathrm{HO}_{2}\right]$ were much higher than in the atmosphere. To calculate $P\left(\mathrm{O}_{3}\right)$ therefore required consideration of ozone photolysis (d) and $\mathrm{O}_{3}$ losses in processes $e-h$ :

Ozone photolysis: The branching ratio of $\mathrm{O}^{1} \mathrm{D}+\mathrm{H}_{2} \mathrm{O}$ reactions in our chamber was: $\mathrm{f}\left(\left[\mathrm{H}_{2} \mathrm{O}\right]\right)$ $\sim 0.09$ and ozone mixing ratios ranged between 46 and 85 ppb. At $\mathrm{J}\left(\mathrm{O}^{1} \mathrm{D}\right)=9 \times 10^{-4} \mathrm{~s}^{-1}$ photolytic ozone losses ranged between 13 and $24 \mathrm{ppb} \mathrm{h}^{-1}$.

Compared to the high photolytic losses, ozone losses in processes $e$ to $h$ were of minor importance. The following loss rates (or upper limits of loss rates) were estimated:

e. Ozone losses in reactions with BVOC were estimated to be $<2 \mathrm{ppb} \mathrm{h}^{-1}$ : BVOC concentrations in the reaction chamber were very low when the TUV lamp was on and $\mathrm{OH}$ reactions were dominant. In such cases concentrations of myrcene, $(E)-\beta$ ocimene exhibiting high reactivity towards $\mathrm{OH}$ were near to the detection limit or even below. These were also the BVOC with the highest reactivity towards $\mathrm{O}_{3}$ and thus ozone losses due to these reactions were not reliably determinable. We therefore estimated an upper limit of $\mathrm{O}_{3}$ losses assuming that a hypothetical BVOC with a high reactivity towards $\mathrm{O}_{3}$ would be abundant at concentrations of $500 \mathrm{ppt}$. As rate constant $\mathrm{k}_{\mathrm{BVOC}}=5.4 \times 10^{-16} \mathrm{~cm}^{3} \mathrm{~s}^{-1}$ was used (= rate constant of $\mathrm{O}_{3}+(E)-\beta$-ocimene reactions, Atkinson, 1997).

f. Using $[\mathrm{OH}]=2.5 \times 10^{7} \mathrm{~cm}^{-3}$ (see Fig. 6 of the manuscript) and $\mathrm{k}_{\mathrm{OH}}=7.3 \times 10^{-14} \mathrm{~cm}^{3} \mathrm{~s}^{-1}$ (Sander et al., 2006) losses in $\mathrm{OH}$ reactions were estimated to $\sim 0.4 \mathrm{ppb} \mathrm{h}^{-1}$. 
g. Assuming $\left[\mathrm{HO}_{2}\right]<0.3 \mathrm{ppb}\left(\sim 8 \times 10^{9} \mathrm{~cm}^{-3}\right)$ as an upper limit for $\mathrm{HO}_{2}$ concentrations (compare to Fig. S1) and using $\mathrm{k}_{\mathrm{HO} 2}=2 \times 10^{-15} \mathrm{~cm}^{3} \mathrm{~s}^{-1}$ (Sander et al., 2006), $\mathrm{O}_{3}$ losses in reactions with $\mathrm{HO}_{2}$ were estimated to $<4 \mathrm{ppb} \mathrm{h}^{-1}$.

h. As reported before (e.g. Neubert et al., 1993; Fares et al., 2008) wall losses in our chamber were very low. Less than $3 \%$ of the $\mathrm{O}_{3}$ was lost within the residence time of the air in the reaction chamber ( 63 min.) leading to an upper limit for ozone wall losses of $<2.6 \mathrm{ppb} \mathrm{h}^{-1}$.

Compared to photolytic $\mathrm{O}_{3}$ losses and losses due to higher $\mathrm{O}_{3}$ concentrations in the outgoing air than in the ingoing air all the other losses (e-h) were low and therefore neglected.

The term of interest, $P\left(\mathrm{O}_{3}\right)=k_{2} \cdot[\mathrm{NO}] \cdot\left[\mathrm{RO}_{2}\right] \cdot Y\left(\mathrm{O}_{3}\right)$, was determined after setting the differential equation for net ozone introduction, photochemical ozone production and ozone photolysis to steady state conditions resulting in Equation ES20:

$P\left(O_{3}\right)=k_{2} \cdot[N O] \cdot\left[R O_{2}\right] \cdot Y\left(O_{3}\right)=\frac{F}{V} \cdot\left(\left[O_{3}\right]-\left[O_{3}\right]_{i n}\right)+J\left(O^{1} D\right) \cdot\left[O_{3}\right] \cdot f\left(\left[H_{2} O\right]\right)$

For comparison with $\mathrm{J}_{7}, P\left(\mathrm{O}_{3}\right)$ was determined for the point in time when new particle formation appeared. For the high $\left[\mathrm{NO}_{\mathrm{x}}\right]_{0}$ experiments $\mathrm{P}\left(\mathrm{O}_{3}\right)$ was thus measured 2 to $5 \mathrm{~h}$ after switching on the TUV lamp. For the low $\left[\mathrm{NO}_{\mathrm{x}}\right]_{0}$ experiments we used the data obtained about an hour after switching on the TUV lamp when $\left[\mathrm{O}_{3}\right]$ was near to steady state.

\section{S3: power law dependencies}

To check for power law dependencies between $\mathrm{J}_{7}$ and BNR and between $\mathrm{P}\left(\mathrm{O}_{3}\right)$ and $\mathrm{BNR}$, respectively, logarithmic data of these data were plotted (Fig. S1).

As result we obtained a slope of: $2.3 \pm 0.1$, for the fit of $\ln \left(\mathrm{J}_{7}\right)$ versus $\ln (\mathrm{BNR})$ indicating that $\mathrm{J}_{7}$ increased approximately in a squared manner with increasing BNR. Considering that $[\mathrm{BVOC}]_{0}$ was quite constant and at least did not vary systematically with $\left[\mathrm{NO}_{\mathrm{x}}\right]_{0}$, this indicates that $\mathrm{J}_{7}$ decreased with increasing $\left[\mathrm{NO}_{\mathrm{x}}\right]_{0}$ in an approximately squared manner. As result of the fit of $\ln \left(\mathrm{P}\left(\mathrm{O}_{3}\right)\right)$ versus $\ln (\mathrm{BNR})$ we obtained $-1.28 \pm 0.3$ indicating that $\mathrm{P}\left(\mathrm{O}_{3}\right)$ increased approximately linearly with decreasing BNR. Again, considering that $[\mathrm{BVOC}]_{0}$ was 
1 quite constant, this also indicated an approximately linear increase of $\mathrm{P}\left(\mathrm{O}_{3}\right)$ with increasing $2\left[\mathrm{NO}_{\mathrm{x}}\right]_{0}$.

3

4

6 In a chemical system with photochemical $\mathrm{O}_{3}$ formation $\frac{\left[\mathrm{NO}_{2}\right]}{[\mathrm{NO}]}$ is given by:

$8 \quad \frac{\left[\mathrm{NO}_{2}\right]}{[\mathrm{NO}]}=\frac{k_{1} \cdot\left[\mathrm{O}_{3}\right]+k_{2} \cdot\left[\mathrm{RO}_{2}\right]}{J\left(\mathrm{NO}_{2}\right)}$

\section{S4: determination of $\left[\mathrm{RO}_{2}\right]$ from deviation from PSS}

10

The difference between measured $\frac{\left[\mathrm{NO}_{2}\right]}{[\mathrm{NO}]}$ and ${\frac{\left[\mathrm{NO}_{2}\right]}{[\mathrm{NO}]}}_{P S S}$ (Equation ES1) is: $\frac{k_{2} \cdot\left[\mathrm{RO}_{2}\right]}{J\left(\mathrm{NO}_{2}\right)}$. The concentration of $\left[\mathrm{RO}_{2}\right]$ can thus be estimated by using an average rate constant $k_{2}$. In two of our experiments it was possible to obtain data for $\left[\mathrm{RO}_{2}\right]$ from observed deviation of $\frac{\left[\mathrm{NO}_{2}\right]}{[\mathrm{NO}]}$ from PSS. We used $k_{2}=9 \times 10^{-12} \mathrm{~cm}^{3} \mathrm{~s}^{-1}$ (IUPAC, 2009) and $\mathrm{J}\left(\mathrm{NO}_{2}\right)=4.3 \times 10^{-3} \mathrm{~s}^{-1}$ as measured in the chamber with VOC free air and in the absence of $\mathrm{O}_{3}$ photolysis by the TUV lamp.

Figure 9 of the manuscript shows the result obtained from the experiment with the highest $\mathrm{NO}_{\mathrm{x}}$ addition (first row of Table 1 in the manuscript). Figure S2 shows the result of the second example where such estimation was possible $\left(\mathrm{BNR}=3.2 \mathrm{ppbC} / \mathrm{ppb},\left[\mathrm{NO}_{\mathrm{x}}\right]_{0}=39.4\right.$ ppb, $[\mathrm{OH}]$ increasing from $5.4 \times 10^{6}$ to $2.2 \times 10^{7} \mathrm{~cm}^{-3}$, third row in Table 1 of the manuscript).

With respect to the temporal development of the photochemical system, the same result was obtained in both experiments. With proceeding photochemistry the deviation of observed $\frac{\left[\mathrm{NO}_{2}\right]}{[\mathrm{NO}]}$ from PSS increased, indicating that peroxy radical concentrations increased with time.

In the experiment shown in Figure S2, new particle formation became observable about 2 hours after starting $\mathrm{OH}$ production. At that time [NO] had decreased from $\sim 9 \mathrm{ppb}$ to $\sim 0.85$ ppb and estimated $\mathrm{RO}_{2}$ concentrations had increased to 200 ppt. In the experiment shown in Figure 9 of the manuscript NPF became observable about 5 hours after starting $\mathrm{OH}$ production. At that time [NO] had decreased from $\sim 20$ to $\sim 1 \mathrm{ppb}$ and estimated $\mathrm{RO}_{2}$ concentrations had increased to $\sim 300 \mathrm{ppt}$. 
2 While absolute concentrations of $\left[\mathrm{RO}_{2}\right]$ depend critically on $\mathrm{k}_{2}$, and therefore have large systematic errors, the relative comparison of $\left[\mathrm{RO}_{2}\right]$ for the two experiments is less error prone. In both experiments the chemical system, especially BVOC composition was similar.

5

\section{S5: Estimation of $\left[\mathrm{RO}_{2}\right]$ for low $\mathrm{NO}_{\mathrm{x}}$ conditions}

As the squared relationship between $\mathrm{J}_{7}$ and $\mathrm{P}\left(\mathrm{O}_{3}\right)$ was valid in the whole range $1.1<\mathrm{BNR}<$ 10 , it was necessary to compare $\left[\mathrm{RO}_{2}\right]$ for all these experiments. Because it was impossible to use deviation from PSS in the medium to low $\mathrm{NO}_{\mathrm{x}}$ experiments, relative data were determined. Reference case was the experiment with the highest $\left[\mathrm{NO}_{\mathrm{x}}\right]_{0}$ addition (Figure 9 in the manuscript).

Relative $\mathrm{RO}_{2}$ concentrations were estimated assuming steady state conditions for peroxy radicals: Due to the high reactivity the lifetime of peroxy radicals is on the order of seconds. This is very short compared to the temporal changes of $[\mathrm{OH}],\left[\mathrm{O}_{3}\right],[\mathrm{NO}]$ in the chamber (see Figs. 4 and 9 in the manuscript and Fig. S2). As production and loss rates changed on time scales of hours, assumption of steady state conditions for $\left[\mathrm{RO}_{2}\right]$ was justified. This assumption allowed expressing $\left[\mathrm{RO}_{2}\right]$ as ratio of $\mathrm{RO}_{2}$ production rates $\mathrm{P}\left(\mathrm{RO}_{2}\right)$ over a loss rate $\mathrm{L}\left(\mathrm{RO}_{2}\right)$ :

$$
\left[R O_{2}\right]=\frac{P\left(R O_{2}\right)}{L\left(R O_{2}\right)}
$$

with

$$
L\left(R O_{2}\right)=k_{2} \cdot[N O]+k_{3} \cdot\left[R O_{2}\right]
$$


1 At the conditions in the chamber, BVOC oxidation was dominated by $\mathrm{OH}$ reactions. Thus

$2 \mathrm{P}\left(\mathrm{RO}_{2}\right)$ could be written as:

3

$4 \quad P\left(\mathrm{RO}_{2}\right)=[\mathrm{BVOC}] \cdot[\mathrm{OH}] \cdot k_{4} \cdot Y\left(\mathrm{RO}_{2}\right)$

5

6 In Equation ES24, $k_{4}$ is an average rate constant for BVOC $+\mathrm{OH}$ reactions and $Y\left(R_{2}\right)$ is the

7 yield of peroxy radical formation from the BVOC mix. The BVOC mixtures during the

8 respective experiments were similar. Therefore also $k_{4}$ and $Y\left(R O_{2}\right)$ were similar allowing expressing the ratio of peroxy radical production rates P(PRP) according to Equation ES25.

$11 \frac{P\left(R O_{2}\right)_{R}}{P\left(R O_{2}\right)_{D}}=\frac{[O H]_{R} \cdot[B V O C]_{0, R}}{[O H]_{D} \cdot[B V O C]_{0, D}}$

In Equation ES25, the index R represents the reference case, and the index D represents the data set for which $\left[\mathrm{RO}_{2}\right]$ had to be determined. In all calculations we used $[\mathrm{OH}]$ as measured during the onset of new particle formation. For the low $\mathrm{NO}_{\mathrm{x}}$ experiments these were the $\mathrm{OH}$ concentrations measured during the first hour of the experiments (see Table 1 in the manuscript). For the high $\mathrm{NO}_{\mathrm{x}}$ experiments these were the $\mathrm{OH}$ concentrations measured $2-5$ $\mathrm{h}$ after the TUV lamp was switched on.

The ratio of $\mathrm{RO}_{2}$ concentrations could be written as:

$$
\frac{\left[R O_{2}\right]_{D}}{\left[R O_{2}\right]_{R}}=\frac{P\left(R O_{2}\right)_{D} \cdot\left(\left[k_{2} \cdot[N O]_{R}+k_{3} \cdot\left[R O_{2}\right]_{R}\right)\right.}{P\left(R O_{2}\right)_{R} \cdot\left(\left[k_{2} \cdot[N O]_{D}+k_{3} \cdot\left[R O_{2}\right]_{D}\right)\right.}
$$

\section{Rearrangement of Equation ES26 leads to Equation ES27:}

$$
\left[R O_{2}\right]_{D}^{2}+\left[R O_{2}\right]_{D} \cdot \frac{k_{2}}{k_{3}}[N O]_{D}-\frac{P\left(R O_{2}\right)_{D}}{P\left(R O_{2}\right)_{R}} \cdot\left[R O_{2}\right]_{R} \cdot\left(\frac{k_{2}}{k_{3}}[N O]_{R}+\left[R O_{2}\right]_{R}\right)=0
$$

$\left[\mathrm{RO}_{2}\right]_{R}$ was $\sim 300$ ppt (see Figure 9 in the manuscript), and $[\mathrm{OH}]_{R}$ was $\sim 2.6 \times 10^{7} \mathrm{~cm}^{-3}$ (see red square in Fig. 6 of the manuscript). $[O H]_{D}$ was measured and $k_{2}$ was set to $9 \times 10^{-12} \mathrm{~cm}^{3} \mathrm{~s}^{-1}$ (IUPAC, 2009) i. e. identical to the value used in the estimations of $\left[\mathrm{RO}_{2}\right]$ from deviation from PSS. 
1 Most uncertain quantities in Equation ES27 were $[N O]_{D}$ and $k_{3}$. Thus, we used upper and

2 lower limits for each of these quantities. As upper limit for $[N O]_{D}$ the NO concentration

3 estimated for PSS from the measured $\left[\mathrm{NO}_{\mathrm{x}}\right]$ and $\left[\mathrm{O}_{3}\right]$ was used. As lower limit, $4 \quad[\mathrm{NO}]_{D}$ was set to zero.

5 To estimate an upper limit for $k_{3}$, it was assumed that $\left[\mathrm{HO}_{2}\right]$ contributed to $90 \%$ to $\left[\mathrm{RO}_{2}\right]$; to estimate a lower limit for $k_{3}$, it was assumed that $\left[\mathrm{HO}_{2}\right]$ contributed to $10 \%$ to $\left[\mathrm{RO}_{2}\right]$. As can be seen from data given in the master chemical mechanism (MCM) for monoterpenes, rate constants for reactions of first generation $\mathrm{RO}_{2}$ radicals with $\mathrm{HO}_{2}$ are much higher than those of other $\mathrm{RO}_{2}-\mathrm{R}^{\prime} \mathrm{O}_{2}$ reactions $\left(\mathrm{RO}_{2}+\mathrm{HO}_{2} \sim 3.1 \times 10^{-11} \mathrm{~cm}^{3} \mathrm{~s}^{-1}, \mathrm{RO}_{2}+\mathrm{R}^{\prime} \mathrm{O}_{2} \sim 6.5 \times 10^{-15}\right.$ $\left.-8.8 \times 10^{-13} \mathrm{~cm}^{3} \mathrm{~s}^{-1}\right)$. This allows neglecting $\mathrm{RO}_{2}+\mathrm{R}^{\prime} \mathrm{O}_{2}$ reactions as important loss terms for peroxy radicals. The relative abundance of $\mathrm{HO}_{2}$ in the $\mathrm{RO}_{2}$ mix is the main determining factor for $\mathrm{RO}_{2}$ loss rates at low $\mathrm{NO}_{\mathrm{x}}$ conditions. We therefore assumed $k_{3}=2.8 \times 10^{-11} \mathrm{~cm}^{3} \mathrm{~s}^{-1}$ (for $\left[\mathrm{HO}_{2}\right] \sim 90 \%$ of $\left[\mathrm{RO}_{2}\right]$ ) to be an upper limit for $k_{3}$ and $k_{3}=3.1 \times 10^{-12} \mathrm{~cm}^{3} \mathrm{~s}^{-1}$ (for $\left[\mathrm{HO}_{2}\right] \sim$ $10 \%$ of $\left[\mathrm{RO}_{2}\right]$ ) to be a lower limit for $k_{3}$.

Table S1 lists $\left[\mathrm{RO}_{2}\right]$ estimated for the three combinations: $k_{3}=2.8 \times 10^{-11} \mathrm{~cm}^{3} \mathrm{~s}^{-1}$ and $[\mathrm{NO}]_{D}$ from PSS termed as $\left[\mathrm{RO}_{2}\right]_{r e l}^{a}, k_{3}=3.1 \times 10^{-12} \mathrm{~cm}^{3} \mathrm{~s}^{-1}$ and $[N O]_{D}$ from PSS termed as $\left[\mathrm{RO}_{2}\right]_{\text {rel }}^{b}$, and for $k_{3}=2.8 \times 10^{-11} \mathrm{~cm}^{3} \mathrm{~s}^{-1}$ and $[\mathrm{NO}]_{D}=0$ termed as $\left[\mathrm{RO}_{2}\right]_{\text {rel }}^{c}$. As obvious from Equation ES27 the fourth of the possible combinations: $k_{3}=3.1 \times 10^{-12} \mathrm{~cm}^{3} \mathrm{~s}^{-1}$ and $[N O]_{D}=0$ gives the same result as $\left[\mathrm{RO}_{2}\right]_{r e l}^{c}$ because $k_{3}$ cancels out. For better comparison, Table S1 also lists the range of minimum and maximum relative $\left[\mathrm{RO}_{2}\right]$ compared to the reference case ( 300 ppt).

Comparing maximum and minimum values for $\left[\mathrm{RO}_{2}\right]$ for individual experiments it is obvious that the data differ by roughly a factor of two. Hence the uncertainty in $\left[\mathrm{RO}_{2}\right]$ caused by the uncertainties in $k_{3}$ and in [NO] had no substantial impact on results for individual experiments. As the variations of $[N O]_{D}$ and $k_{3}$ were quite large, we believe that the estimations on the ranges of relative $\left[\mathrm{RO}_{2}\right]$ are realistic.

Comparing relative $\mathrm{RO}_{2}$ concentrations between experiments starting at high $\left[\mathrm{NO}_{\mathrm{x}}\right]_{0}$ conditions and at low $\left[\mathrm{NO}_{\mathrm{x}}\right]_{0}$, respectively, it is obvious that also these numbers show variability of roughly a factor of 2 . Independent of the combination of $k_{3}$ and [NO] used for the estimations there was no systematic variation from high to low $\mathrm{NO}_{\mathrm{x}}$ experiments (compare numbers in columns). 
Again, we put not too much attention to the absolute numbers. But the photochemical systems were very similar from experiment to experiment allowing reliable comparison between experiments. We therefore concluded that $\left[\mathrm{RO}_{2}\right]$ at the onset of NPF was quite constant in all experiments. Contrary, $\mathrm{J}_{7}$ varied by 3 orders of magnitude over the whole BNR range. In the range $1.1<\mathrm{BNR}<10$ where comparison of $\mathrm{J}_{7}$ and $\mathrm{P}\left(\mathrm{O}_{3}\right)$ was possible $\mathrm{J}_{7}$ still varied by 2 orders of magnitude allowing the conclusion that $\mathrm{J}_{7}$ was not related to $\mathrm{P}(\mathrm{PRP})$.

\section{S6 Sensitivity tests and general considerations}

Based on the similarity of $\left[\mathrm{RO}_{2}\right]$ estimated for the high and low $\left[\mathrm{NO}_{\mathrm{x}}\right]_{0}$ experiments, respectively, we conclude that production rates of first generation PRP were not the rate limiting step for NPF. We further test the validity of this conclusion with the following hypothesis. We assume that first permutation reactions of first generation $\mathrm{RO}_{2}$ radicals are the rate limiting step for NPF and estimate how high $\left[\mathrm{RO}_{2}\right]$ should have been in that case during the low $\left[\mathrm{NO}_{\mathrm{x}}\right]_{0}$ experiments:

If reaction $\mathrm{R} 3$ is the rate limiting step in new particle formation, $\mathrm{J}_{7}$ should be proportional to the rate of reaction $\mathrm{R} 3$ :

$J_{7}=x \cdot k_{3} \cdot\left[\mathrm{RO}_{2}\right] \cdot\left[\mathrm{RO}_{2}\right]$

with $\mathrm{x}=$ a proportionality factor.

As base we again use the high $\mathrm{NO}_{\mathrm{x}}$ experiment as shown in Fig. 9 of the manuscript. When particle formation started, $\mathrm{RO}_{2}$ was estimated to be around 300 ppt and $\mathrm{J}_{7}$ was in the range of $0.13 \mathrm{~cm}^{-3} \mathrm{~s}^{-1}$. As typical value for $\mathrm{J}_{7}$ at low $\mathrm{NO}_{\mathrm{x}}$ conditions we use $\mathrm{J}_{7}=66 \mathrm{~cm}^{-3} \mathrm{~s}^{-1}$ (average of $\mathrm{J}_{7}$ without $\mathrm{NO}_{\mathrm{x}}$ addition, see Table 1 in the manuscript). Assuming the proportionality factor $x$ to be constant would mean that threshold $\mathrm{RO}_{2}$ concentrations should increase with the square root of $\mathrm{J}_{7}$. Using $\mathrm{J}_{7}=66 \mathrm{~cm}^{-3} \mathrm{~s}^{-1}$ leads to a threshold $\mathrm{RO}_{2}$ concentration of $6.8 \mathrm{ppb}$. Assuming that the dependence of $\mathrm{J}_{7}$ on $\left[\mathrm{RO}_{2}\right]$ would be to power law of 1.6 instead of 2 would lead to even higher $\left[\mathrm{RO}_{2}\right]$ of $49 \mathrm{ppb}$.

Both values for $\left[\mathrm{RO}_{2}\right], 6.8$ and $49 \mathrm{ppb}$ are unrealistic high even when considering that the absolute numbers for $\mathrm{RO}_{2}$ as shown in Fig. 9 may be an order of magnitude too high. The strong variations in $\mathrm{J}_{7}$ cannot at all be explained by variations of $\left[\mathrm{RO}_{2}\right]$. 
From our estimations in sections S4 to S6 we conclude that permutation reactions of first generation $\mathrm{RO}_{2}$ radicals cannot be the rate limiting step for new particle formation.

\section{S7 Determination of $\mathbf{J}_{7}$ and estimation of uncertainty limits for $\mathbf{J}_{7}$}

Determining rates of new particle formation $\left(\mathrm{J}_{7}\right)$ from chamber data requires consideration of wall losses and of background particles. Both may skew determinations of $J_{7}$ if their impact on $\mathrm{J}_{7}$ is substantial.

We used BVOC concentrations around $10 \mathrm{ppb}$ and, as also found in other studies (e.g. Mentel et al., 2009, Mentel et al., 2013), formation of new particles from ozonolysis alone was low as long as BVOC concentrations in that range were applied. Therefore also the background particle number concentration formed from ozonolysis of $\alpha$-pinene and from the $\mathrm{OH}$ formed during ozonolysis was low. Without $\mathrm{NO}_{\mathrm{x}}$ addition the particle number concentration $\left(\mathrm{P}_{\mathrm{N}}\right)$ of the background ranged between $100 \mathrm{~cm}^{-3}$ and $300 \mathrm{~cm}^{-3}$. Background $\mathrm{P}_{\mathrm{N}}$ was quite constant during individual experiments with fluctuations $<10 \%$. Inducing NPF by OH formation (TUV lamp on) increased $\mathrm{P}_{\mathrm{N}}$ to $\sim 3 \times 10^{4} \mathrm{~cm}^{-3}$ (see Fig. 3 in the manuscript, red trace). Since the maximum $\mathrm{P}_{\mathrm{N}}$ was much higher than fluctuations of background number concentrations, $\mathrm{J}_{7}$ was not substantially skewed by background particles, since it was determined from the slope of $\mathrm{P}_{\mathrm{N}}$ versus time.

$\mathrm{NO}_{\mathrm{x}}$ addition to the chemical system decreased $\mathrm{J}_{7}$ as well as the background particle numbers. At $\left[\mathrm{NO}_{\mathrm{X}}\right] \geq 40 \mathrm{ppb}$, background $\mathrm{P}_{\mathrm{N}}$ were between $3 \mathrm{~cm}^{-3}$ and $7 \mathrm{~cm}^{-3}$ and fluctuated from $\sim 1$ $\mathrm{cm}^{-3}$ to $\sim 11 \mathrm{~cm}^{-3}$. Compared to the maximum $\mathrm{P}_{\mathrm{N}}$ determined during NPF events at $\left[\mathrm{NO}_{\mathrm{x}}\right] \geq 40$ ppb $\left(130-2200 \mathrm{~cm}^{-3}\right)$ these fluctuations are still small. Assuming that no particles were introduced into the chamber and all background particles were produced in the chamber, we estimate the upper limit of $7 \mathrm{~nm}$ particles formed as background using the maximum particle number of $11 \mathrm{~cm}^{-3}$ and the residence time of the air in the chamber (63 min). This results in max. background $\mathrm{J}_{7} \sim 0.0032 \mathrm{~cm}^{-3} \mathrm{~s}^{-1}$. This is by far lower than the lowest $\mathrm{J}_{7}$ determined during our experiments. Considering this as worst case estimation, we assess possible errors in $\mathrm{J}_{7}$ determinations due to background particles as low over the whole range of applied $\mathrm{NO}_{\mathrm{X}}$.

To estimate the impacts of wall losses on $\mathrm{J}_{7}$ the following experiment was conducted using two different CPCs in parallel. One was a TSI 3022A with a cut off diameter of $7 \mathrm{~nm}$, the other one was a TSI 3786 coupled to a particle size magnifier (PSM, Airmodus A09) with a nominal cut-off diameter of $1.5 \mathrm{~nm}$ for the PSM/CPC system. Ten ppb $\alpha$-pinene and $80 \mathrm{ppb}$ 
$1 \mathrm{O}_{3}$ were added to the chamber (without $\mathrm{NO}_{\mathrm{X}}$ addition). Before starting the photolytic 2 production of $\mathrm{OH}$ radicals, the system was in steady state showing stable number concentrations around $130 \mathrm{~cm}^{-3}$ particles $>1.5 \mathrm{~nm}$ and $\sim 11 \mathrm{~cm}^{-3}$ for particles with diameters

$4>7 \mathrm{~nm}$. Short after photolytic production of $\mathrm{OH}$ radicals, $\mathrm{P}_{\mathrm{N}}$ measured by the PSM increased rapidly to $\sim 1500 \mathrm{~cm}^{-3}$ within about 1.5 minutes. Then the $\mathrm{OH}$ production was switched off and $\mathrm{P}_{\mathrm{N}}$ as measured with the PSM decreased exponentially indicating a first order loss process (loss coefficient $-0.0017 \pm 0.0001 \mathrm{~s}^{-1}, \mathrm{R}^{2}=0.9, \tau=9.8 \mathrm{~min}$.). $\mathrm{P}_{\mathrm{N}}$ as measured with the $7 \mathrm{~nm}$ CPC stayed constant at $~ 11$ over the whole measurement period proving that particles with diameters $>7 \mathrm{~nm}$ did not substantially contribute to $\mathrm{P}_{\mathrm{N}}$ during that experiment. From this we conclude that the exponential decay observed for the number concentration of particles with diameters between 1.5 and $7 \mathrm{~nm}$ was mainly due to wall losses of small particles. The loss coefficient of $0.0017 \mathrm{~s}^{-1}$, equivalent to a lifetime of about 10 minutes, indicated that wall losses in our chamber had substantial impact on the observation of formation rates of new particles.

To consider the impacts of wall losses, $\mathrm{J}_{7}$ was determined in the following manner. It was assumed that new particle formation and wall losses were the dominant processes and that impacts of outflow and coagulation on $\mathrm{P}_{\mathrm{N}}$ were negligible. This led to the approach:

$J_{7}=\frac{\partial\left(P_{N}\right)}{\partial t}+L\left(P_{N}\right)$

In equation ES29, $\frac{\partial\left(P_{N}\right)}{\partial t}$ is the first derivative of the measured $\mathrm{P}_{\mathrm{N}}$ as a function of time at the inflection point. $\mathrm{L}\left(\mathrm{P}_{\mathrm{N}}\right)$ is the loss rate and calculated as product of loss coefficient and $\mathrm{P}_{\mathrm{N}}$ at the respective inflection points.

Depending on the experiment the contributions of $\frac{\partial\left(P_{N}\right)}{\partial t}$ and $\mathrm{L}\left(\mathrm{P}_{\mathrm{N}}\right)$ to $\mathrm{J}_{7}$ were different. At high $\frac{\partial\left(P_{N}\right)}{\partial t}, \mathrm{~L}\left(\mathrm{P}_{\mathrm{N}}\right)$ and $\frac{\partial\left(P_{N}\right)}{\partial t}$ were similar in magnitude indicating that even at the fastest temporal increases of $\mathrm{P}_{\mathrm{N}}, \mathrm{J}_{7}$ was already affected by wall losses. At the lowest measured $\frac{\partial\left(P_{N}\right)}{\partial t}, \mathrm{~L}\left(\mathrm{P}_{\mathrm{N}}\right)$ exceeded $\frac{\partial\left(P_{N}\right)}{\partial t}$ by a factor of 6 indicating that for small $\frac{\partial\left(P_{N}\right)}{\partial t}$ the loss rates dominate $\frac{\partial\left(P_{N}\right)}{\partial t}$. Hence, the uncertainty of wall losses determines the error in $\mathrm{J}_{7}$. Therefore different wall losses were used to calculate uncertainty limits for $\mathrm{J}_{7}$. We estimated the uncertainty limits for $\mathrm{J}_{7}$ by doubling and halving the measured loss coefficient, respectively. The upper limit was estimated using a loss coefficient of $0.0034 \mathrm{~s}^{-1}$ corresponding to a 
1 lifetime of 5 minutes. The lower limit for $\mathrm{J}_{7}$ was estimated using a loss coefficient of 0.00085

$2 \mathrm{~s}^{-1}$ corresponding to a lifetime of 20 minutes. 


\section{References to supplemental information}

Atkinson, R.: Gas-phase tropospheric chemistry of volatile organic compounds: 1 . Alkanes and alkenes. J. Phys. Chem. Reference Data, 26, (2), 215-290, 1997.

Fares, S., Loreto, F., Kleist, E., and Wildt, J.: Stomatal uptake and stomatal deposition of ozone in isoprene and monoterpene emitting plants. Plant Biology, 10, 44 - 54, 2008.

Hallquist, M., Wenger, J. C., Baltensperger, U., Rudich, Y., Simpson, D., Claeys, M., Dommen, J., Donahue, N. M., George, C., Goldstein A. H., Hamilton J. F., Herrmann, H., Hoffmann, T., Iinuma, Y., Jang M., Jenkin M. E., Jimenez, J. L., Kiendler-Scharr, A., Maenhaut, W., McFiggans, G., Mentel Th. F., Monod A., Prévôt, A. S. H., Seinfeld, J. H., Surratt, J. D., Szmigielski R., and Wildt, J.: The formation, properties and impact of secondary organic aerosol: current and emerging issues. Atmos. Chem. Phys., 9, 51555236, 2009.

IUPAC Subcommittee for Gas Kinetic Data Evaluation, http://www.iupackinetic.ch.cam.ac.uk/, 2009.

Leighton, P. A.: Photochemistry of Air Pollution. Academic Press, San Diego, CA, USA, 1961.

Master Chemical Mechanism, MCM: http://mcm.leeds.ac.uk/MCM/roots.htt

Mentel, Th. F., Wildt, J., Kiendler-Scharr, A., Kleist, E., Tillmann, R., Dal Maso, M., Fisseha, R., Hohaus, Th., Spahn, H., Uerlings, R., Wegener, R., Griffiths, P. T., Dinar, E., Rudich, Y., and Wahner, A.: Photochemical production of aerosols from real plant emissions, Atmos. Chem. Phys., 9, 4387-4406, doi:10.5194/acp-9-4387-2009, 2009.

Mentel, Th. F., Kleist, E., Andres, S., Dal Maso, M., Hohaus, T., Kiendler-Scharr, A., Rudich, Y., Springer, M., Tillmann, R., Uerlings, R., Wahner, A., and Wildt, J.: Secondary aerosol formation from stress-induced biogenic emissions and possible climate feedbacks, Atmos. Chem. Phys., 13, 8755-8770, doi:10.5194/acp-13-8755-2013, 2013.

Neubert, A., Kley, D., Wildt, J., Segschneider, H. J., and Förstel, H.: Uptake of NO, $\mathrm{NO}_{2}$ and $\mathrm{O}_{3}$ by sunflower and tobacco: dependence on stomatal conductivity. Atmos. Environm. 27A, 2137-2145, 1993.

Sander, S. P., Friedl, R. R., Golden, D. M., Kurylo, M. J., Moortgat, G. K., Keller-Rudek, H., Wine P. H., Ravishankara, A. R., Kolb , C. E., Molina, M. J., Finlayson-Pitts, B. J., Huie, R. E., and Orkin, V. L.: Chemical Kinetics and Photochemical Data for Use in 
1 Atmospheric Studies, Evaluation Number 15, JPL Publication 06-2, 2 http://jpldataeval.jpl.nasa.gov/, 2006.

3

4

5 
1 Table S1: Results from estimations of relative peroxy radical concentrations. Data for $\left[\mathrm{RO}_{2}\right]$

2 obtained for the experiment at $\mathrm{BNR}=1.1$ were taken as reference.

$3\left[\mathrm{RO}_{2}\right]_{\mathrm{rel}}^{a}: k_{3}=2.8 \times 10^{-11} \mathrm{~cm}^{3} \mathrm{~s}^{-1},[N O]_{D}$ from PSS,

$4 \quad\left[R O_{2}\right]_{r e l}^{b}: k_{3}=3.1 \times 10^{-12} \mathrm{~cm}^{3} \mathrm{~s}^{-1},[N O]_{D}$ from PSS,

$5 \quad\left[R O_{2}\right]_{\text {rel }}^{c, d}: k_{3}=2.8 \times 10^{-11} / 3.1 \times 10^{-12} \mathrm{~cm}^{3} \mathrm{~s}^{-1},[N O]_{D}=0$.

6 The last column lists the minimum and maximum $\left[\mathrm{RO}_{2}\right]$ compared to 300 ppt, i.e. the

7 reference case.

8

\begin{tabular}{|c|c|c|c|c|c|c|c|}
\hline $\begin{array}{c}\text { BNR } \\
{[\mathrm{ppbC]/[ppb]}}\end{array}$ & $\begin{array}{c}{[\mathrm{BVOC}]_{0}} \\
{[\mathrm{ppbC}]}\end{array}$ & $\begin{array}{c}{[\mathrm{OH}]} \\
{\left[\mathrm{cm}^{-3}\right]} \\
\times 10^{7} \\
\end{array}$ & $\begin{array}{c}{\left[\mathrm{RO}_{2}\right]_{P S S}} \\
{[\mathrm{ppt}]}\end{array}$ & $\begin{array}{c}{\left[\mathrm{RO}_{2}\right]_{\text {rel }}^{a}} \\
{[\mathrm{ppt}]}\end{array}$ & $\begin{array}{c}{\left[\mathrm{RO}_{2}\right]_{\text {rel }}^{b}} \\
{[\mathrm{ppt}]}\end{array}$ & $\begin{array}{c}{\left[\mathrm{RO}_{2}\right]_{\text {rel }}^{c, d}} \\
{[\mathrm{ppt}]}\end{array}$ & $\begin{array}{c}\text { Range } \\
\%\end{array}$ \\
\hline 1.1 & 119 & 2.58 & 300 & - & - & - & - \\
\hline 1.8 & 122 & 2.50 & \# & 169 & 150 & 299 & $50-100$ \\
\hline 3.2 & 124.5 & 2.20 & 200 & 164 & 136 & 283 & $45-94$ \\
\hline 4.3 & 98.5 & $*$ & -- & $*$ & $*$ & $*$ & $*$ \\
\hline 8.9 & 109.5 & 1.68 & -- & 149 & 95 & 232 & $31-77$ \\
\hline 10.2 & 104.3 & 1.89 & -- & 164 & 102 & 240 & $34-80$ \\
\hline 12.8 & 105 & $*$ & -- & $*$ & $*$ & $*$ & $*$ \\
\hline 14.4 & 106.3 & 1.91 & -- & 181 & 115 & 244 & $38-81$ \\
\hline 18.0 & 88.3 & 1.83 & -- & 168 & 98 & 218 & $33-73$ \\
\hline 24.4 & 79.8 & 1.71 & -- & 162 & 91 & 200 & $30-67$ \\
\hline 25.4 & 124.5 & 1.47 & -- & 183 & 111 & 232 & $37-77$ \\
\hline 28.6 & 117 & 1.71 & -- & 200 & 124 & 242 & $41-81$ \\
\hline 29.8 & 97.5 & 1.68 & -- & 182 & 108 & 219 & $36-73$ \\
\hline 61.1 & 100 & 1.40 & -- & 181 & 112 & 203 & $37-68$ \\
\hline 62.0 & 101.5 & $*$ & -- & $*$ & $*$ & $*$ & $*$ \\
\hline 79.2 & 129.5 & 0.99 & -- & 172 & 104 & 194 & $35-65$ \\
\hline 255.8 & 76.8 & $*$ & -- & $*$ & $*$ & $*$ & $*$ \\
\hline 277.5 & 83.3 & 1.58 & -- & 192 & 164 & 196 & $54-65$ \\
\hline 300.0 & 90 & 1.59 & -- & 201 & 172 & 205 & $57-68$ \\
\hline 326.7 & 98 & 1.06 & -- & 170 & 140 & 175 & $47-58$ \\
\hline 329.2 & 98.8 & $*$ & -- & $*$ & $*$ & $*$ & $*$ \\
\hline 345.8 & 103.8 & 1.16 & -- & 183 & 155 & 188 & $51-63$ \\
\hline 363.8 & 109 & $*$ & -- & $*$ & $*$ & $*$ & $*$ \\
\hline 412.5 & 124 & $*$ & -- & $*$ & $*$ & $*$ & $*$ \\
\hline 414.2 & 124.3 & 1.11 & -- & 197 & 168 & 201 & $56-67$ \\
\hline 415.0 & 124.5 & $*$ & -- & $*$ & $*$ & $*$ & $*$ \\
\hline
\end{tabular}

$9--$ - [NO] too low to allow reliably determination of deviation from PSS

$10{ }^{\#}$ no $\left[\mathrm{RO}_{2}\right]_{P S S}$ due to failure of $\mathrm{NO}_{\mathrm{x}}$ analytics

$11 *$ no data due to failure of $\mathrm{OH}$ measurement

12

13

14 
2

3

4

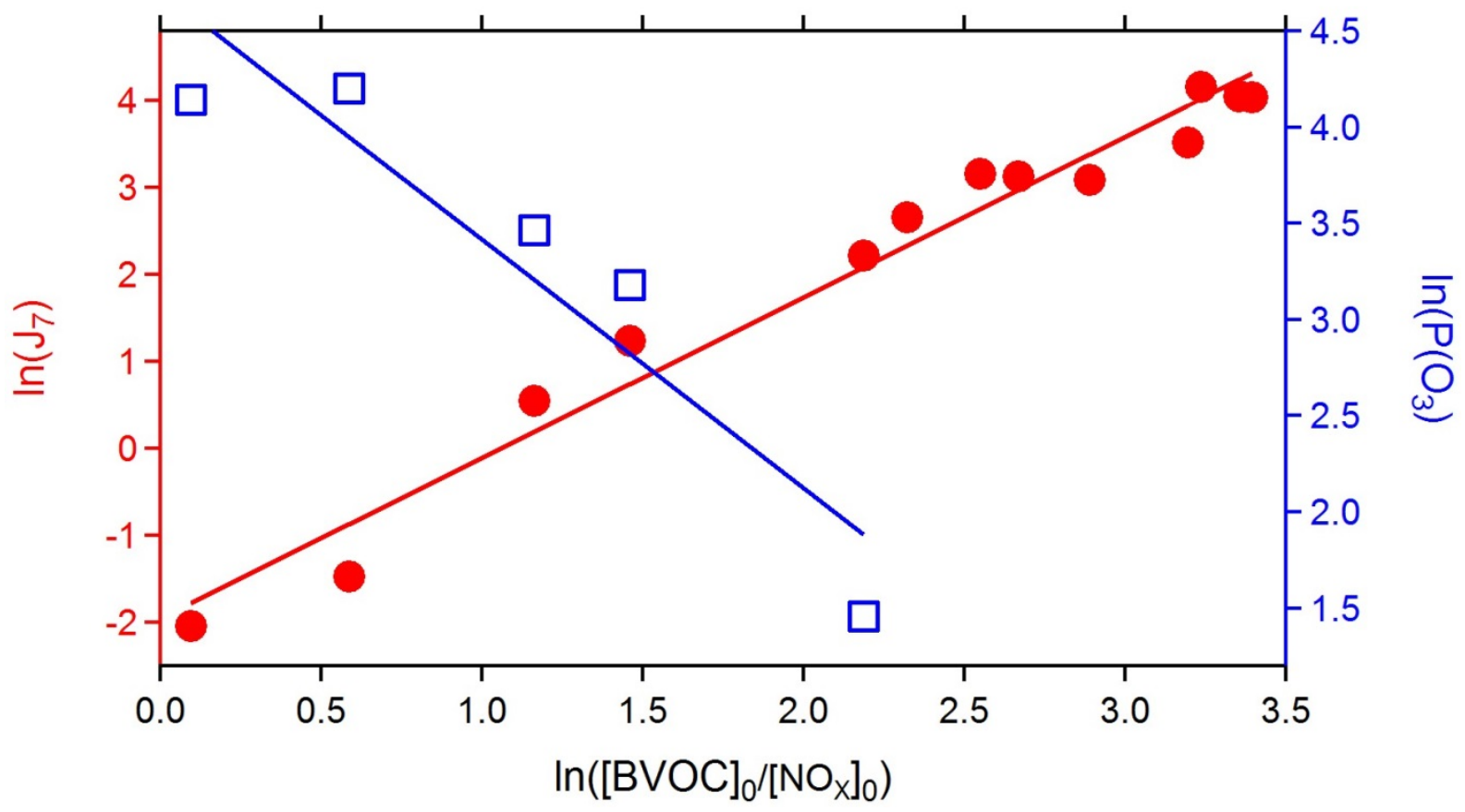

Fig. S1: double logarithmic plots of $J_{7}$ versus BNR (left scale, red circles) and of $P\left(O_{3}\right)$ versus BNR (blue squares, right scale). The red and blue lines show the results from the respective least square fits. Data used for the fit of $\ln \left(\mathrm{J}_{7}\right)$ versus $\ln (\mathrm{BNR})$ were restricted to data points where impacts of $\mathrm{NO}_{\mathrm{x}}$ were obvious (BNR $\left.<30[\mathrm{ppbC}] /[\mathrm{ppb}]\right)$. Data used for the fit of $\ln \left(\mathrm{P}\left(\mathrm{O}_{3}\right)\right.$ versus $\ln (\mathrm{BNR})$ were restricted to reliable data for $\mathrm{P}\left(\mathrm{O}_{3}\right)\left(\mathrm{P}\left(\mathrm{O}_{3}\right)>2.5 \mathrm{ppb} \mathrm{h}^{-1}\right)$. Note the different scales at both y-axes. 


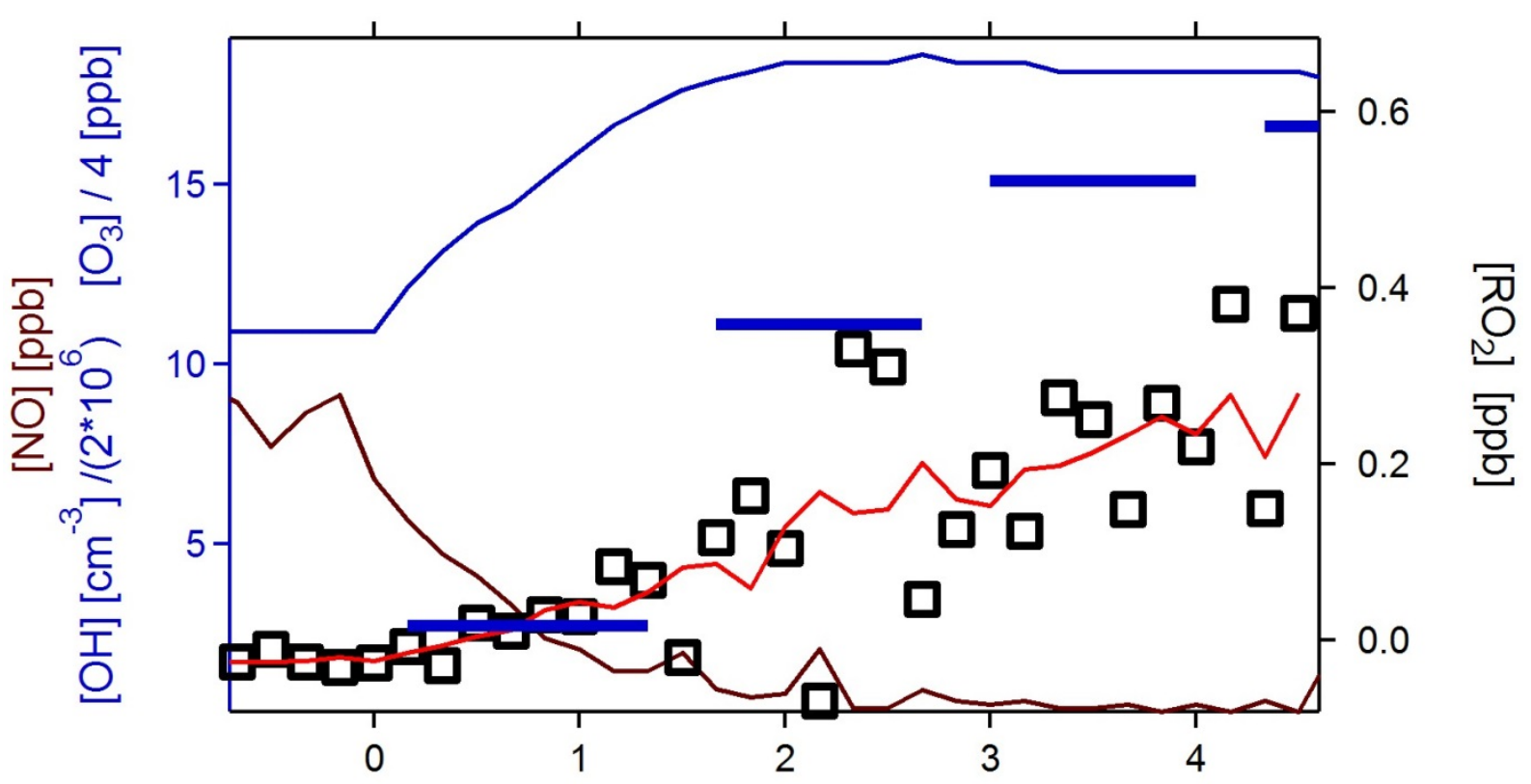

$6 \quad$ Fig. S2: Estimated $\left[\mathrm{RO}_{2}\right]\left(=\sum\left[\mathrm{RO}_{2}^{i}\right]\right)$ using deviation from PSS and an average rate constant $7 \quad k_{2}=9 \times 10^{-12} \mathrm{~cm}^{3} \mathrm{~s}^{-1}$ for reaction R2. The open squares (right hand y-scale) show the original 8 data; the red line shows the five point moving average of the $\left[\mathrm{RO}_{2}\right]$ data (right hand $\mathrm{y}$-scale). 9 The brown line shows NO concentrations measured during that experiment, the blue bars show $\mathrm{OH}$ concentrations divided by $2 \times 10^{6}$ for clarity, and the blue line shows the ozone concentrations divided by 4 for clarity (all data on left hand y-scale). New particle formation

12 started about $2 \mathrm{~h}$ after the TUV lamp was switched on. At that point in time [NO] had 13 decreased to $\sim 0.8 \mathrm{ppb}$ and $\left[\mathrm{RO}_{2}\right]$ had increased to $\sim 200 \mathrm{ppt}$. 